\title{
The association between serum testosterone levels and coronary artery disease in middle-aged men
}

\author{
Ahmet Baris Durukan ${ }^{1}$, Hasan Alper Gurbuz ${ }^{1}$, Ali Cevat Tanalp ${ }^{1}$, Elif Durukan², Halil Ibrahim Ucar ${ }^{1}$, \\ Cem Yorgancioglu ${ }^{1}$
}

${ }^{1}$ Medicana International Ankara Hospital, Turkey

${ }^{2}$ Baskent University Medical Faculty, Turkey

Kardiochirurgia i Torakochirurgia Polska 2013; 10 (3): 211-215

\begin{abstract}
Background: The relation between coronary artery disease (CAD) and the levels of serum androgen has been revealed in various population studies. The Gensini coronary scoring system is used to evaluate the degree of coronary stenosis, taking into account its location and producing a numerical score.

The aim of the study was to explore the association between serum testosterone levels and both the presence and severity of coronary artery disease indicated by the Gensini score in middle-aged men.
\end{abstract}

Material and methods: Between October 2011 and April 2012, 124 middle-aged (40-59) male patients with known or suspected coronary artery disease were included in the study. Coronary angiography was performed in all patients, and their Gensini scores were calculated. Total serum testosterone levels were also measured.

Results: The mean Gensini score of the patients was $44.11 \pm 39.08$ The mean plasma testosterone level was $3.51 \pm 1.39 \mathrm{ng} / \mathrm{ml}$. There was no correlation between the severity of coronary artery disease and the serum testosterone levels $(r=-0.161, p>0.05)$. When the patients with coronary artery disease (Gensini score $\geq 1$ ) were compared with the patients without it $(n=29$, Gensini score: 0 ), their mean serum testosterone levels were revealed to be lower $(p=0.043)$. There was no correlation between the testosterone levels and the high-density lipoprotein cholesterol and triglyceride levels. There was a correlation between the serum testosterone levels and total cholesterol levels $(p=0.008)$, lowdensity lipoprotein cholesterol levels $(p=0.019)$, and body mass index $(p=0.001)$.

Conclusions: The mean serum testosterone levels were lower in the CAD group. We did not manage to document their relation with disease severity by means of the Gensini score.

Key words: coronary artery disease, testosterone, Gensini coronary score.

\section{Streszczenie}

Wprowadzenie: Związek pomiędzy chorobą wieńcową a stężeniami androgenów w surowicy został stwierdzony przez autorów różnych badań populacyjnych. Skala Gensiniego ocenia stopień zwężeń wieńcowych, biorąc pod uwagę ich umiejscowienie.

Celem niniejszej pracy było zbadanie związku pomiędzy surowiczym stężeniem testosteronu a obecnością choroby wieńcowej i jej nasileniem (według skali Gensiniego) u mężczyzn w średnim wieku.

Materiał i metody: Pomiędzy październikiem 2011 r. a kwietniem 2012 r. do badania włączono 124 mężczyzn w średnim wieku (40-59 lata), u których stwierdzono bądź podejrzewano chorobę wieńcową. Wszyscy chorzy zostali poddani angiografii wieńcowej i obliczono dla nich wynik w skali Gensiniego. Zmierzono również całkowite stężenia testosteronu.

Wyniki: Średni wynik pacjentów w skali Gensiniego wyniósł $44,11 \pm 39,08$. Średnie stężenie testosteronu w plazmie wynosito $3,51 \pm 1,39 \mathrm{ng} / \mathrm{ml}$. Nie wykryto korelacji pomiędzy nasileniem choroby wieńcowej a surowiczym stężeniem testosteronu $(r=-0,161, p>0,05)$. Kiedy porównano pacjentów z chorobą wieńcową (wynik w skali Gensiniego $\geq 1$ ) z pacjentami, którzy nie cierpieli na tę chorobę ( $n=29$, wynik skali Gensiniego: 0 ), okazało się, że ich średnie stężenia testosteronu w surowicy były niższe $(p=0,043)$. Nie wykryto korelacji pomiędzy stężeniami testosteronu a stężeniami cholesterolu - lipoproteiny wysokiej gęstości oraz trójglicerydów. Wystąpiła korelacja pomiędzy stężeniami testosteronu w surowicy oraz całkowitymi stężeniami cholesterolu $(p=0,008)$, cholesterolu - lipoproteiny niskiej gęstości $(p=0,019)$ oraz wskaźnikiem BMI $(p=0,001)$. Wnioski: Średnie stężenia testosteronu w surowicy były niższe u pacjentów z chorobą wieńcową. Nie udało się udokumentować ich związku z nasileniem choroby za pomocą skali Gensiniego.

Słowa kluczowe: choroba wieńcowa, testosteron, skala Gensiniego.

Address for correspondence: Ahmet Baris Durukan, Medicana International Ankara Hospital, Umit Mahallesi 2463. sokak Sedef Sitesi 4/18, Yenimahalle, 06810 Ankara, Turkey, phone: +905322273814, fax: +903122203170, e-mail: barisdurukan@yahoo.com 


\section{Introduction}

Coronary artery disease (CAD) is a multi-factorial disease involving environmental, genetic, and pathophysiological processes. It is associated with high rates of mortality and morbidity. The disease remains the number one cause of death in the West, and is becoming increasingly more prevalent in developing countries. Male gender is considered to be a major risk factor contributing to atherosclerosis, which has been attributed to the male sex hormone, testosterone (T). Contrarily, in 1984 Moller and Einfeldt postulated that this increased cardiovascular risk does not reflect a simple positive relationship with $T$ and even that $T$ is protective against vascular disease [1]. From the enormous and growing amount of data, we now know that $T$ has cardiovascular metabolic effects, and deficiency of this androgenic hormone has been shown to increase the risk of premature $C A D$, which supports the work by Moller and Einfeldt [2]. Testosterone deficiency is a predictor of cardiovascular mortality, independent of age [3].

Population-based studies were carried out with regard to the relation between low androgen levels and CAD. Akishita et al. [4] demonstrated that a low androgen level is a predictor of cardiovascular events in Japanese men with cardiovascular risk factors. Similarly, Hu et al. [5] and Zhao et al. [6] revealed androgen deficiency to be a risk factor for the development of CAD in Chinese men. In a study conducted in a Swedish population, Ohlsson et al. [7] concluded that high $\mathrm{T}$ levels predicted a reduced 5-year risk of cardiovascular events in elderly men. Moreover, it was demonstrated that T supplementation has beneficial metabolic effects in men with androgen deficiency [8].

In light of the mentioned studies, we hypothesized that a low $T$ level is an independent risk factor for CAD in middle-aged men with cardiovascular risk factors. Therefore, we aimed to explore the association between serum $\mathrm{T}$ levels and both the presence and severity of CAD.

\section{Material and methods \\ Study population}

The study followed the Declaration of Helsinki on medical protocol and was approved by the Institutional Medical Ethics Committee. Written informed consent was obtained from every patient. Between November 2011 and April 2012, 124 male patients with known or suspected CAD, aged between 40 and 59 years, were examined prospectively. Coronary artery angiography was performed in all patients. Physical examination, chest X-ray, laboratory value assessment, echocardiography with wall motion analysis and Doppler screening were performed to exclude structural heart diseases. Patients with fever, arrhythmias, liver or renal dysfunction, autoimmune disease, and cancer were excluded.

\section{Sample collection and biochemical investigation}

Blood samples for the analysis of basal hormone levels were obtained between 8:00 and 9:00 AM after an overnight fast, and at least 24 hours from symptom onset for those presenting with acute coronary syndrome. The levels of serum total T were measured using commercially prepared immunoassay kits in accordance with the manufacturer's instructions $\left(\right.$ Abbott $^{\circledR}$, ARCHITECT i1000SR, Illinois, USA). Serum total cholesterol (TC), triglyceride (TG), high-density lipoprotein cholesterol (HDL-C), and low-density lipoprotein cholesterol (LDL-C) levels were measured with standard laboratory techniques. Cardiovascular risk factors were noted based on patient records and individual questioning.

\section{Determination of the severity of coronary artery stenosis}

The severity of coronary artery stenosis was estimated using the Gensini coronary scoring system. The Gensini system scores the narrowing of the coronary artery lumen as follows: $1-25 \%$ narrowing: 1, 26-50\% narrowing: 2, 51-75\% narrowing: 4, 76-90\% narrowing: 8, 91-99\% narrowing: 16 , and total occlusion: 32 . The score was then multiplied by a factor that represented the importance of the lesion's position in the coronary arterial tree: left main coronary artery: $(\times 5)$, proximal left anterior descending artery: $(\times 2.5)$, middle segment: $(\times 1.5)$, apical branch: $(\times 1)$, first diagonal branch: $(\times 1)$, second diagonal branch: $(\times 0.5)$, proximal left circumflex artery: $(\times 2.5)$, obtuse marginal branch: $(\times 1)$, distal segment: $(\times 1)$, posterior descending branch: $(\times 1)$, posterolateral branch: $(\times 0.5)$, proximal right coronary artery: $(\times 1)$, middle segment: $(\times 1)$, distal segment: $(\times 1)$, and posterior descending branch: $(\times 1)$. If a patient had multiple lesions, then the aggregate score of all the lesions of this patient was the total CAD severity score [9].

\section{Statistical analysis}

Statistical analyses were performed using SPSS software for Windows version 17.0 (Statistical Package for the Social Sciences Inc., Chicago, IL, USA). Continuous variables were expressed as mean values \pm standard deviation. Categorical variables were expressed as numbers and percentages. Demographic characteristics and outcomes of the groups were compared using an independent samples t-test for continuous variables and a chi-square test and Fisher's exact test for categorical variables. Statistical significance was set as ' $p<0.05$ '.

The association between serum $T$ levels and other parameters was evaluated using Pearson's correlation analysis. Statistical significance was set as ' $p<0.05$ '.

\section{Results}

One hundred and twenty-four patients were included in the study. The mean age of the patients was $51.76 \pm 5.47$. The mean Gensini score of the patients was $44.11 \pm 39.08$. The mean plasma T level was $3.51 \pm 1.39 \mathrm{ng} / \mathrm{ml}$. The demographic characteristics of patients are presented in Table I.

All patients were examined in order to evaluate whether there was an association between the severity of CAD (indicated by Gensini score) and serum T levels, but no cor- 
Tab. I. Demographic characteristics of patients

\begin{tabular}{|c|c|c|c|c|}
\hline Factor & $\begin{array}{c}\text { Total } \\
\text { Mean } \pm \text { SD (Min-Max) }\end{array}$ & $\begin{array}{c}\text { CAD (-) } \\
\text { Mean } \pm S D\end{array}$ & $\begin{array}{c}\text { CAD (+) } \\
\text { Mean } \pm \text { SD }\end{array}$ & $p$ value \\
\hline Age & $51.76 \pm 5.47(40-59)$ & $49.31 \pm 6.04$ & $52.51 \pm 5.09$ & 0.005 \\
\hline Gensini Score & $44.11 \pm 39.08(0-180)$ & - & $57.58 \pm 34.85$ & - \\
\hline Testosterone (ng/ml) & $3.51 \pm 1.39(0.07-8.71)$ & $3.97 \pm 1.46$ & $3.37 \pm 1.34$ & 0.043 \\
\hline BMI $\left(\mathrm{kg} / \mathrm{m}^{2}\right)$ & $28.55 \pm 4.49(19.60-48.55)$ & $28.45 \pm 4.34$ & $28.58 \pm 4.56$ & 0.890 \\
\hline $\mathrm{TC}(\mathrm{mg} / \mathrm{dl})$ & $196.58 \pm 49.52(90-373)$ & $206.79 \pm 60.45$ & $193.46 \pm 45.58$ & 0.206 \\
\hline LDL-C (mg/dl) & $123.02 \pm 45.67(19-308)$ & $127.79 \pm 52.81$ & $121.57 \pm 43.46$ & 0.523 \\
\hline $\mathrm{HDL}-\mathrm{C}(\mathrm{mg} / \mathrm{dl})$ & $37.94 \pm 11.89(12-116)$ & $42.76 \pm 8.79$ & $36.47 \pm 12.36$ & 0.012 \\
\hline TG (mg/dl) & $171.44 \pm 107.15(33-672)$ & $149.10 \pm 99.27$ & $178.25 \pm 109.02$ & 0.201 \\
\hline \multirow[t]{2}{*}{$\mathrm{EF}(\%)$} & $55.83 \pm 10.51(20-71)$ & $60.38 \pm 5.75$ & $54.44 \pm 11.25$ & 0.007 \\
\hline & $n(\%)$ & $n(\%)$ & $n(\%)$ & $p$ value $^{b}$ \\
\hline DM & $34(27.4)$ & $5(17.2)$ & $29(30.5)$ & 0.160 \\
\hline HT & $51(41.1)$ & $8(27.6)$ & $43(45.3)$ & 0.090 \\
\hline Smoking (Current/Ex) & $98(79.0)$ & $21(72.4)$ & $77(81.1)$ & 0.317 \\
\hline $\mathrm{PAD}^{\mathrm{C}}$ & $4(3.2)$ & $1(3.4)$ & $3(3.2)$ & $1.000^{d}$ \\
\hline Stroke/Carotid Stenosis ${ }^{\mathrm{e}}$ & $1(0.08)$ & - & $1(1.1)$ & $1.000^{d}$ \\
\hline
\end{tabular}

aindependent samples $t$-test, ${ }^{b} \chi^{2}$ test, ${ }^{c}$ History of therapeutic vascular intervention, history of claudication, or peripheral arterial disease confirmed by angiogra-

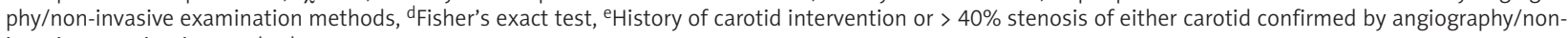
invasive examination methods

CAD - coronary artery disease, BMI - body mass index, TC - total cholesterol, LDL-C - low-density lipoprotein cholesterol, HDL-C - high-density lipoprotein cholesterol, TG - triglyceride, EF - ejection fraction, DM - diabetes mellitus, HT - hypertension, PAD - peripheral arterial disease

relation was found $(r=-0.161, p>0.05)$ (Table II). Similarly, there was no correlation between T levels and HDL-C levels and TG levels. However, there was a correlation between serum T levels and TC levels ( $r=0.236, p=0.008), \mathrm{LDL}-\mathrm{C}$ levels $(r=-0.210, p=0.019)$ and body mass index (BMI) $(r=-0.286, p=0.001)$.

Twenty-nine patients had a Gensini score of 0 . Following the evaluation of all patients, the patients with a Gensini score of 0 were assigned to the non-CAD group, whereas the ones with scores over 1 were assigned to the CAD group. The association between serum $T$ levels and the presence of CAD was then evaluated. The mean level of serum testosterone was $3.97 \pm 1.46$ in the non-CAD group, whereas in patients with CAD it was $3.37 \pm 1.34$. There was a statistically significant difference between the two groups $(p=0.043)$, and the serum $T$ levels were lower in the CAD group. The comparison between the two groups is presented in detail in Table I.

We also studied the association between $T$ levels and other parameters in patients with CAD. The findings were consistent with the previous results concerning all the patients. There was no correlation between the $T$ levels and the Gensini score $(r=-0.071, p>0.05)$, HDL levels, and TG levels. There was a correlation between the serum $T$ levels and the TC levels $(r=0.246, p=0.016)$, LDL-C levels $(r=-0.247, p=0.016)$, and BMI $(r=-0.242, p=0.018)$.

\section{Discussion}

Molecular studies are becoming increasingly important in understanding the association between androgen levels and coronary atherosclerosis. Testosterone affects smooth muscle tone, the coagulation cascade, and vascular intima and media, leading to pathological changes. In hypogonadal men with CAD, T supplementation therapy increases the serum levels of interleukin-10, which has anti-atherosclerotic properties. In hypogonadal animals fed with a high-fat diet, $T$ administration decreases fatty streak formation. In animal (castrated male swine) models of post-angioplasty restenosis, $T$ administration decreases neointimal formation associated with increased coronary smooth muscle apoptosis [10]. Testosterone treatment was also shown to reduce interleukin-6 and C-reactive protein levels, which may cause post-surgery restenosis [11]. Testosterone also exerts its vasodilatory effect on the vascular endothelium by the inactivation of L-type calcium channels

Tab. II. Correlation between serum testosterone levels and other parameters

\begin{tabular}{lcccc} 
& \multicolumn{2}{c}{ Total } & \multicolumn{2}{c}{ CAD $(+)$} \\
& $r$ & $p$ & $r$ & $p$ \\
Gensini Score & -0.161 & 0.074 & -0.071 & 0.493 \\
\hline TC $(\mathrm{mg} / \mathrm{dl})$ & 0.236 & 0.008 & 0.246 & 0.016 \\
\hline LDL-C $(\mathrm{mg} / \mathrm{dl})$ & 0.210 & 0.019 & 0.247 & 0.016 \\
\hline HDL-C $(\mathrm{mg} / \mathrm{dl})$ & 0.081 & 0.372 & 0.041 & 0.692 \\
\hline TG $(\mathrm{mg} / \mathrm{dl})$ & -0.044 & 0.627 & -0.057 & 0.584 \\
\hline BMl $\left(\mathrm{kg} / \mathrm{m}^{2}\right)$ & -0.286 & 0.001 & -0.242 & 0.018 \\
\hline CAD $-\mathrm{cos}$
\end{tabular}

CAD - coronary artery disease, TC - total cholesterol, LDL-C - low-density lipoprotein cholesterol, HDL-C - high-density lipoprotein cholesterol, TG - triglyceride, $\mathrm{BMI}$ - body mass index 
and/or the activation of potassium channels. Testosterone levels correlate negatively with pro-thrombotic fibrinogen and plasminogen activator inhibitor-1, and positively with anticoagulant tissue plasminogen activator [12].

The complexity of the atherosclerotic process and the broad spectrum of metabolic activities of serum androgens complicate the clinical side of the equation. We know that, with advancing age, the serum androgen levels decline [13]. The androgen deficiency is closely related to a metabolic syndrome defined by the co-existence of atherosclerotic risk factors, such as central abdominal obesity, increased TG and decreased HDL-C levels, hypertension, impaired fasting glucose, and hyperlipidemia. Decreased androgen levels may also lead to type 2 diabetes mellitus if symptoms progress $[12,14]$. Furthermore, this decline also leads to age-related diseases such as erectile dysfunction, osteoporosis, cognitive impairment, and mood changes [4]. Based on animal studies, it was revealed that androgens have a protective effect on vascular health [1].

Most of the studies designed to explore the association between serum androgen levels and coronary atherosclerosis are population studies, which is significant because of ethnic differences. In a population study performed on 87 Chinese middle-aged men, the serum $\mathrm{T}$ levels were found to be lower among CAD patients and were also negatively correlated with their Gensini scores [5]. Zhao et al. [6] conducted their study in China as well, including over 102 patients and 99 healthy subjects. The serum T levels were higher in the non-CAD group in comparison to the CAD patients. Our results are consistent with the previous studies, although there was a difference when the serum levels were compared. The serum $T$ levels were lower in the diseased group of Chinese men compared to our study $(2.51 \pm 1.25$ vs. $3.37 \pm 1.34 \mathrm{ng} / \mathrm{ml})$ and higher in the non-CAD group (4.11 \pm 3.07 vs. $3.97 \pm 1.46)$ [6]. Hu et al. [5] also documented testosterone levels in the nonCAD group that were higher than in our study $(5.62 \pm 1.10)$. This is probably due to ethnic differences. In our study, the number of patients in the non-CAD group was much lower than the number of CAD patients, which may have affected the evaluation of the results and their reliability. Moreover, the mean age of the patients in the non-CAD group was lower than that in the CAD group, which may have prevented us from drawing more reliable conclusions.

However, when studies from Turkey are considered, differences in terms of serum $T$ levels can also be observed. Iltimur et al. [15] documented mean plasma testosterone levels of $3.6 \pm 0.8 \mathrm{ng} / \mathrm{ml}$ in patients with metabolic syndrome and $4.8 \pm 1.9 \mathrm{ng} / \mathrm{ml}$ in the control group. Their control levels are also higher than ours, but their study consisted of a lower number of patients. Turhan et al. [2] compared 69 CAD patients with 56 control patients and documented lower $\mathrm{T}$ levels in the diseased population (3.08 \pm 1.69 vs. $4.08 \pm 2.05 \mathrm{ng} / \mathrm{ml}$ ); these values are comparable with those revealed by the present study.

In their prospective study of 171 patients, Akashita et al. [4] concluded that lower serum $T$ levels were associated with cardiovascular events in middle-aged Japanese men. However, the definition of 'middle-aged' in their study covered a wider age spectrum, namely men between the ages of 30 and 69; we believe this range is very broad and does not truly reflect the mentioned age interval. Notwithstanding, the study is valuable in terms of revealing the association of $\mathrm{T}$ levels with cardiovascular events. In a similar, but broader study conducted in Sweden, Ohlsson et al. [7] prospectively followed 2416 men aged between 69 and 81 years and demonstrated that men with serum $T$ levels in the highest quartile experienced the lowest percentage of cardiovascular events during the following 5-year period. We did not analyze the occurrence of cardiovascular events throughout the study.

We failed to document a relationship between CAD severity, conveyed by Gensini score, and serum T levels, unlike Zhao et al. [5]. They also documented a positive correlation with LDL-C levels and a negative correlation with TG levels. In turn, our study documented a positive correlation with TC levels and a negative correlation with BMI and LDL-C levels. Iltimur et al. [14] documented a negative correlation with BMI (similar to our results), but also found a negative correlation with HDL-C and TG levels, and no correlation with TC and LDL-C levels. Finally, Hu et al. [5] documented only a negative correlation with BMI.

Our study only aimed to document the relation between the presence/severity of CAD and serum T levels; therefore, the patients were not categorized according to whether they had been admitted with stable or unstable angina pectoris or acute myocardial infarction.

Based on the aforementioned facts concerning the correlation of lower androgen levels with CAD, T administration has been speculated to have therapeutic effects, but for now, evidence for this is only available with regard to hypogonadal men [16]. We believe that patients with T levels that are low, but remain within the normal range, may also be candidates for therapy; nonetheless, there is still insufficient clinical data to support this idea.

The majority of human observational studies concluded that the incidence of CAD is higher among men with lower serum T levels [17]. Significant improvements in diagnostic and therapeutic methods are likely to occur as we further our understanding of the pathophysiological processes that underlie coronary artery disease, its association with serum androgen levels, and the role of $\mathrm{T}$ in its treatment.

\section{Conclusions}

We demonstrated that the serum $T$ levels in the patients without CAD were higher than the ones in the patients with CAD. However, the relatively small size of the patient population does not allow us to draw reliable conclusions. Studies with larger numbers of patients are required for more accurate results.

\section{Limitations}

Serum T level is a parameter which is influenced heavily by ethnic characteristics. Since this study aimed to docu- 
ment its relation with CAD among men in Turkey, a multicentre study could be conducted in Turkey to document the population characteristics.

\section{The authors declare no competing interests.}

\section{References}

1. Traish AM, Kypreos KE. Testosterone and cardiovascular disease: an old idea with modern clinical implications. Atherosclerosis 2011; 214: 244-248.

2. Turhan S, Tulunay C, Gulec S, Ozdol C, Kilickap M, Altin T, Gerede M, Erol C. The association between androgen levels and premature coronary artery disease in men. Coron Artery Dis 2007; 18: 159-162.

3. Webb CM, Collins M. Testosterone and coronary artery disease in men. Maturitas 2010; 67: 15-19.

4. Akishita M, Hashimoto M, Ohike Y, Ogawa S, lijima K, Eto M, Ouchi Y. Low testosterone level as a predictor of cardiovascular events in Japanese men with coronary risk factors. Atherosclerosis 2010; 210: 232-236.

5. Hu X, Rui L, Zhu T, Xia H, Yang X, Wang X, Liu H, Lu Z, Jiang H. Low testosterone level in middle-aged male patients with coronary artery disease. Eur J Intern Med 2011; 22: e133-e136.

6. Zhao S, Li X. The association of low plasma testosterone level with coronary artery disease in Chinese men. Int J Cardiol 1998; 63: 161-164.

7. Ohlsson C, Barrett-Connor E, Bhasin S, Orwoll E, Labrie F, Karlsson MK, Ljunggren Ö, Vandenput L, Mellström D, Tivesten A. High serum testosterone is associated with reduced risk of cardiovascular events in elderly men. J Am Coll Cardiol 2011; 58: 1674-1681.
8. Yeap BB. Androgens and cardiovascular disease. Curr Opin Endocrinol Diabetes Obes 2010; 17: 269-276.

9. Shihan W, Jie W, Ji L. Relationship between the Gensini score of blood-stasis syndrome in coronary heart disease and VEGF. Mode Tradit Chin Med Mater Med 2010; 12: 355-357.

10. Corona G, Rastrelli G, Vignozzi L, Mannucci E, Maggi M. Testosterone, cardiovascular disease and the metabolic syndrome. Best Pract Res Clin Endocrinol Metabol 2011; 25: 337-353.

11. Guler N, Batyraliev T, Dulger H, Ozkara C, Tuncer M, Aslan S, Okut H, Agirbasli $M$. The effects of short term (3 weeks) testosterone treatment on serum inflammatory markers in men undergoing coronary artery stenting. Int J Cardiol 2006; 109: 339-343.

12. Jones TH, Saad F. The effects of testosterone on risk factors for, and the mediators of, the atherosclerotic process. Atherosclerosis 2009; 207: 318-327.

13. Muller M, den Tonkelaar I, Thijssen JH, Grobbee DE, van der Schouw YT. Endogenous sex hormones in men aged 40-80 years. Eur J Endocrinol 2003; 149: 583-589.

14. Jones TH. Testosterone deficiency: a risk factor for cardiovascular disease. Trends Endocrin Met 2010; 21: 496-503.

15. Ittimur K, Karabulut A, Toprak G, Yokus B, Toprak N. Evaluation of testosterone levels in men with metabolic syndrome. Arch Turk Soc Cardiol 2005; 33: 447-451.

16. Webb CM, Collins P. Testosterone and coronary artery disease in men. Maturitas 2010; 67: 15-19.

17. Kaushik M, Sontineni SV, Hunter C. Cardiovascular disease and androgens: a review. Int J Cardiol 2010; 142: 8-14. 